\title{
Hubungan Status Gizi dan Genetik dengan Usia Menstruasi Pertama (Menarche) pada Siswi SMP Negeri 17 Banda Aceh Tahun 2016
}

\author{
The Relationship between Nutrition and Genetic Status with Menstrual Age \\ (Menarche) in 2016 Students of Banda Aceh Middle School 17
}

\author{
Raudhatun Nuzul ZA*1, Maulidani \\ ${ }^{1}$ Program Studi D-IV Bidan Pendidik,Fakultas Ilmu Kesehatan, Universitas Ubudiyah Indonesia, Banda Aceh, Indonesia \\ ${ }^{2}$ Program Studi D-III Kebidanan, Fakultas Ilmu Kesehatan, Universitas Ubudiyah Indonesia, Banda Aceh, Indonesia \\ *Korespondensi Penulis: raudhatun@uui.ac.id
}

\begin{abstract}
Abstrak
Menarche merupakan tanda awal masuknya seorang perempuan dalam masa reproduksi. Berdasarkan hasil riset kesehatan dasar tahun 2010 terdapat 5,2\% anak-anak di 17 Provinsi di Indonesia telah memasuki usia menarche di bawah usia 12 tahun. Menarche dapat terjadi lebih awal pada usia 9-10 tahun atau lebih lambat pada usia 17 tahun. Berdasarkan data yang diperoleh dari SMP Negeri 17 Banda Aceh terdiri dari 27 kelas dengan jumlah keseluruhan sisiwi putri 372 orang. terdapat bahwa hampir seluruh siswi yang mengalami menarche pada usia >12 tahun. Metode Penelitian :Jenis penelitian bersifat analitik dengan pendekatan crossectional yang dilakukan di SMP Negeri 17 Banda Aceh pada bulan Juni jumlah sampel dalam penelitian ini sebanyak 79 orang dengan tehknik random sampling Pengumpulan data menggunakan kuesioner dan uji statistik menggunakan Uji korelasi. Berdasarkan hasil uji statistik, adanya hubungan status Gizi Dengan Usia Menstruasi Pertama (Menarche) Pada Siswi, dengan nilai $\mathrm{P}$ value $=0,000$ adanya hubungan genetik Dengan Usia Menstruasi Pertama (Menarche) Pada Siswi, dengan nilai $\mathrm{P}$ value=0,000. Ada hubungan antara status gizi, genetik dengan usia menstruasi pertama (Menarche) Diharapkan unutk dapat menambah pengetahuan siswa tentang hubungan status gizi dan genetik dengan usia menarche.
\end{abstract}

Kata Kunci : Status Gizi, Genetik dan Menarche

\begin{abstract}
Menarche is the initial sign of the entry of a woman during reproduction. Based on the results of basic health research in 2010 there were 5.2\% of children in 17 provinces in Indonesia who had entered the age of menarche under the age of 12 years. Menarche can occur earlier at the age of 9-10 years or later at the age of 17 years. Based on data obtained from 17th State Middle School Banda Aceh consisting of 27 classes with a total number of female students 372 people. there are almost all students who experience menarche at> 12 years of age. Research Method: This type of research is analytical with crossectional approach conducted in Banda Aceh State Junior High School 17 in June. The number of samples in this study was 79 people with random sampling techniques. Data collection using questionnaires and statistical tests using correlation test. Research Results: Based on the results of statistical tests, there is a relationship between Nutrition with the First Menstrual Age (Menarche) on Students, with a value of $P$-value $=0,000$ for genetic relations with Menstrual Age at
\end{abstract}


Students, with a $P$ value $=0,000$. There is a relationship between nutritional status, genetics with the age of the first menstruation (Menarche). It is expected to be able to increase students' knowledge about the relationship of nutritional status and genetic age with menarche.

Keywords: Nutritional Status, Genetics and Menarche

\section{PENDAHULUAN}

Remaja adalah tubuh manusia mengalami berbagai perubahan dari waktu kewaktu sejak lahir yang meliputi pertumbuhan dan perkembangan. Perubahan yang cukup mencolok terjadi ketika anak perempuan dan laki-laki memasuki usia antara 9-15 tahun. Pada saat itu mereka tidak hanya tumbuh menjadi lebih tinggi dan lebih besar, tetapi juga terjadi perubahan-perubahan di dalam tubuh yang memungkinkan untuk bereproduksi. Masa inilah yang disebut dengan masa pubertas atau masa remaja ( Proverawati, 2009 ).

Menurut $W H O$ sekitar seperlima dari penduduk remaja dunia dari remaja berumur 10 - 19 tahun. Sekitar 900 juta berada di negara yang sedang berkembang. Data demografi dari Amerika Serikat menunjukkan jumlah remaja berumur 10 - 19 tahun. Di Indonesia menurut Biro Pusat Statistik kelompok umur 10 - 19 tahun adalah 22\%. Yang terdiri dari 50,9\% remaja laki - laki dan $49,1 \%$ remaja perempuan.

Menurut hasil UNICEF WHO The World Bank Join Chil malnutrision estimate 2012, di perkirakan 165 juta anak di bawah 5 tahun diseluruh dunia mengalami sunted mengalami penurunan di bandingkan sebanyak 253 tahun 1990. Tingkat prevalensi stunting tinggi di kalangan anak di bawah usia 5 tahun terdapat di Afrika ( 36\% ) dan Asia ( 27\% ), dan sering belum di akui sebagai masalah kesehatan masyarakat ( Kesmas, 2013 ).

Berdasarkan data Kemenkes RI (2010), diketahui bahwa di Indonesia terjadi penurunan usia menarche. Berdasarkan hasil riset kesehatan dasar tahun 2010 terdapat 5,2\% anak-anak di 17 Provinsi di Indonesia telah memasuki usia menarche di bawah usia 12 tahun.

Menarche merupakan tanda awal masuknya seorang perempuan dalam masa reproduksi. Rata-rata usia menarche pada umumnya adalah 12,4 tahun. Menarche dapat terjadi lebih awal pada usia 9-10 tahun atau lebih lambat pada usia 17 tahun. Hasil Riskesdas menunjukkan bahwa berdasarkan laporan responden yang sudah mengalami haid, rata-rata usia menarche di Indonesia adalah 13 tahun (20,0\%) dengan kejadian lebih awal pada usia kurang dari 9 tahun dan ada yang lebih lambat sampai 20 tahun serta 7,9\% tidak 
menjawab/lupa. Terdapat 7,8\% yang melaporkan belum haid. Secara nasional rata-rata usia menarche 13-14 tahun terjadi pada 37,5\% anak Indonesia (Riset Kesehatan Dasar, 2010).

Maulidiah (2011), mengatakan faktor genetik berperan mempengaruhi percepatan dan perlambatan menarche yaitu antara usia menarche ibu dengan usia menarche putrinya. Faktor genetik merupakan faktor yang tidak bisa dimodifikasi. Usia untuk mencapai fase terjadinya menarche dipengaruhi oleh banyak faktor antara lain faktor gizi, suku, genetik, sosial, ekonomi, dan lain-lain. Faktor gizi mempengaruhi kematangan seksual. Pada remaja yang mendapat menarche lebih dini, mereka cenderung lebih berat dan lebih tinggi pada saat menarche dibandingkan dengan yang belum menstruasi pada usia yang sama. Umumnya, remaja yang mengalami kematangan seksual lebih dini akan memiliki indeks massa tubuh yang lebih tinggi. Peran genetik juga dianggap berpengaruh pada usia kematangan seorang wanita ( Proverawati, 2009 ).

Pada tahun 1990, provelensi gizi kurang dan gizi buruk sebanyak 31\% sedangkan pada tahun 2010 terjadi penurunan 17,9\%. Berdasarkan data Rikesdes 2010, prevalensi gizi lebih pada balita sebesar 14,0\%, meningkat dari keadaan tahun 2007 yaitu sebesar 12,2\%. Masalah gizi lebih paling mengkhawatirkan terjadi pada perempuan dewasa yang mencapai 26,9\% dan laki - laki dewasa sebesar 16.3\% ( Kesmas, 2013 ).

Berdasarkan data yang diperoleh dari SMP Negeri 17 Banda Aceh terdiri dari 27 kelas dengan jumlah keseluruhan sisiwi putri 372 orang. Kelas VII terdiri dari 9 kelas dengan jumlah siswi putrinya 136 orang, kelas VIII terdiri dari 9 kelas dengan jumlah siswi putrinya 105 orang, dan kelas XI terdiri dari 9 kelas dengan jumlah siswi putrinya 131 orang.Berdasarkan fenomena tentang status gizi dan genetik dengan usia menarche, penulis tertarik untuk melakukan penelitian di SMP Negeri 17 Banda Aceh denganjudul " Hubungan Status Gizi Dan Genetik Dengan Menstruasi Pertama Pada Siswi SMP Negeri 17 Banda Aceh.

\section{METODE PENELITIAN}

Jenis penelitian ini bersifat analitikdengan cross secctional, yaitu variabel dependen dan variabel independen diteliti secara sekaligus pada waktu yang sama (Notoatmodjo, 2010). Menggunakan jumlah sampel sebanyak 372 orang siswi yang menjadi responden dalam penelitian ini. Teknik Pengumpulan Data dalam penelitian ini menggunakan data primer dan data sekunder. Menggunakan uji statistik chi-square. 


\section{HASIL DAN PEMBAHASAN}

Tabel 1. Distribusi Frekuensi Status Gizi Padasiswi SMP Negeri 17 Banda Aceh Tahun 2016

\begin{tabular}{|c|c|c|}
\hline IMT & Frekuensi (f) & Persentase $(\%)$ \\
\hline 14.1 & 1 & 1.3 \\
\hline 14.2 & 1 & 1.3 \\
\hline 14.5 & 1 & 1.3 \\
\hline 15.1 & 1 & 1.3 \\
\hline 15.4 & 1 & 1.3 \\
\hline 15.6 & 2 & 2.5 \\
\hline 16.2 & 1 & 1.3 \\
\hline 16.3 & 1 & 1.3 \\
\hline 16.4 & 1 & 1.3 \\
\hline 16.5 & 1 & 1.3 \\
\hline 16.6 & 5 & 6.3 \\
\hline 16.9 & 1 & 1.3 \\
\hline 17.3 & 3 & 3.8 \\
\hline 17.5 & 2 & 2.5 \\
\hline 17.6 & 2 & 2.5 \\
\hline 17.8 & 3 & 3.8 \\
\hline 17.9 & 1 & 1.3 \\
\hline 18 & 2 & 2.5 \\
\hline 18.1 & 1 & 1.3 \\
\hline 18.3 & 1 & 1.3 \\
\hline 18.4 & 2 & 2.5 \\
\hline 18.6 & 1 & 1.3 \\
\hline 18.7 & 1 & 1.3 \\
\hline 18.9 & 1 & 1.3 \\
\hline 19 & 2 & 2.5 \\
\hline 19.1 & 3 & 3.8 \\
\hline 19.2 & 1 & 1.3 \\
\hline 19.5 & 1 & 1.3 \\
\hline 19.6 & 1 & 1.3 \\
\hline 20 & 3 & 3.8 \\
\hline 20.3 & 2 & 2.5 \\
\hline 20.4 & 2 & 2.5 \\
\hline 20.5 & 2 & 2.5 \\
\hline 21.4 & 2 & 2.5 \\
\hline 21.5 & 1 & 1,3 \\
\hline 22 & 1 & 1.3 \\
\hline
\end{tabular}




\begin{tabular}{ccc}
22.2 & 1 & 1.3 \\
22.3 & 1 & 1.3 \\
22.4 & 1 & 1.3 \\
22.6 & 1 & 1.3 \\
22.8 & 1 & 1.3 \\
23.4 & 1 & 1.3 \\
23.5 & 2 & 2.5 \\
23.8 & 1 & 1.3 \\
24.1 & 1 & 1.3 \\
24.4 & 1 & 1.3 \\
25 & 1 & 1.3 \\
25.3 & 2 & 2.5 \\
25.4 & 1 & 1.3 \\
26.2 & 1 & 1.3 \\
26.4 & 1 & 1.3 \\
26.5 & 1 & 1.3 \\
29.6 & 2 & 2.5 \\
\hline Total & $\mathbf{7 9}$ & $\mathbf{1 0 0 . 0}$ \\
\hline
\end{tabular}

Berdasarkantabel 4.1 Dapat disimpulkan bahwa dari 79 respoden yang IMT 16.6 sebanyak 5 responden $(6,3 \%)$.

Tabel 2. Distribusi Frekuensi Genetik Pada Siswi SMP Negeri 17 Banda Aceh Tahun 2016

\begin{tabular}{ccc}
\hline Genetik(usia) & Frekuensi (f) & Persentase $(\%)$ \\
\hline 10.5 & 2 & 2.5 \\
11 & 1 & 1.3 \\
11.5 & 6 & 7.6 \\
12 & 12 & 15.2 \\
12.5 & 31 & 39.2 \\
13 & 21 & 26.6 \\
13.5 & 5 & 6.3 \\
14 & 1 & 1.3 \\
\hline Total & 79 & 100.0 \\
\hline
\end{tabular}

Berdasarkan table 4.2Dapat disimpulkan bahwa dari 79 respoden yang Genetik 12.5 sebanyak 31 responden $(39,2 \%)$ 
Tabel 3. Distribusi Frekuensi Usia Menstruasi Pada Siswi SMP Negeri 17 Banda Aceh Tahun 2016

\begin{tabular}{|c|c|c|}
\hline Usia Menarche & Frekuensi (f) & Persentase $(\%)$ \\
\hline 9 & 2 & 2.5 \\
\hline 10 & 2 & 2.5 \\
\hline 10.5 & 5 & 6.3 \\
\hline 10.7 & 1 & 1.3 \\
\hline 11 & 4 & 5.1 \\
\hline 11.5 & 1 & 1.3 \\
\hline 11.8 & 1 & 1.3 \\
\hline 12 & 11 & 13.9 \\
\hline 12.2 & 3 & 3.8 \\
\hline 12.3 & 4 & 5.1 \\
\hline 12.4 & 3 & 3.8 \\
\hline 12.5 & 5 & 6.3 \\
\hline 12.6 & 1 & 1.3 \\
\hline 12.8 & 1 & 1.3 \\
\hline 13 & 8 & 10.1 \\
\hline 13.2 & 3 & 3.8 \\
\hline 13.3 & 4 & 5.1 \\
\hline 13.4 & 1 & 1.3 \\
\hline 13.5 & 8 & 10.1 \\
\hline 13.6 & 1 & 1.3 \\
\hline 14 & 2 & 2.5 \\
\hline 14.2 & 1 & 1.3 \\
\hline 14.3 & 1 & 1.3 \\
\hline 14.5 & 3 & 3.8 \\
\hline 14.6 & 1 & 1.3 \\
\hline 14.7 & 1 & 1.3 \\
\hline 15 & 1 & 1.3 \\
\hline Total & 79 & 100.0 \\
\hline
\end{tabular}

Berdasarkan table 4.3 Dapat disimpulkan bahwa dari 79 respoden yang usia Menstruasi 12 tahun sebanyak 11 responden $(13,9 \%)$. 
Tabel 4. Hubungan Status Gizi dengan Usia Menstruasi Pertama (Menarche) Pada Siswi SMP Negeri17 Banda AcehTahun 2016

\begin{tabular}{|c|c|c|c|}
\hline & & IMT & Usia Menarche \\
\hline IMT & $\begin{array}{l}\text { Pearson Correlation } \\
\text { Sig. (2-tailed) } \\
\text { N }\end{array}$ & $\begin{array}{l}` 1 \\
79\end{array}$ & $\begin{array}{r}0,520 \\
0,000 \\
79\end{array}$ \\
\hline Usia menarche & $\begin{array}{l}\text { Pearson Corellation } \\
\text { Sig. (2-tailed) } \\
\text { N }\end{array}$ & $\begin{array}{l}-0,520 \\
0,000 \\
79\end{array}$ & $\begin{array}{l}` 1 \\
79\end{array}$ \\
\hline
\end{tabular}

Berdasarkan tabel 4 dapat menujukkan bahwa setelah dilakukan uji korelasi person dan sperrman maka diperoleh nilai $P$ value $=0,000$, yang sangat signifikan adanya hubungan status Gizi Dengan Usia Menstruasi Pertama (Menarche) Pada Siswi Smp Negeri 17 Banda AcehTahun 2016.

Tabel 5. Hubungan Genetik dengan Usia Menstruasi Pertama (Menarche) pada Siswi SMP Negeri 17 Banda AcehTahun 2016

\begin{tabular}{|l|l|r|r|}
\hline & & Genetik & Usia Menarche \\
\hline Status Genetik & Pearson Correlation & -1 & 0,621 \\
& Sig. (2-tailed) & 79 & 0,000 \\
& N & 0,621 & 79 \\
\hline Usia menarche & Pearson Corellation & 0,000 & -1 \\
& Sig. (2-tailed) & 79 & 79 \\
& N & & \\
\end{tabular}

Berdasarkan tabel 5 dapat menujukkan bahwa Setelah dilakukan uji korelasi person dan sperrman maka diperoleh nilai $P$ value $=0,000$, yang sangat signifikan adanya hubungan genetik Dengan Usia Menstruasi Pertama (Menarche) Pada Siswi Smp Negeri 17 Banda AcehTahun 2016.

\section{Pembahasan}

1. Hubungan Status Gizi Dengan Usia Menstruasi Pertama (Menarche) Pada Siswi

Berdasarkan hasil penelitian yang telah dilakukan dapat menujukkan bahwa Setelah dilakukan uji korelasi person dan sperrman maka diperoleh nilai $P$ value $=0,000$, yang signifikan adanya hubungan status Gizi Dengan Usia Menstruasi Pertama (Menarche) Pada Siswi SMP Negeri 17 Banda AcehTahun 2016. 
Menurut penelitian Nurrahmawati (2016), status gizi remaja wanita sangat mempengaruhi terjadinya menarche baik dari faktor usia terjadinya menarche, adanya keluhan-keluhan selama menarche maupun lamanya hari menarche. Nutrisi mempengaruhi kematangan seksual pada gadis yang mendapatkan menstruasi pertama lebih dini, mereka cenderung lebih berat dan lebih tinggi pada saat menstruasi pertama dibandingkan dengan mereka yang belum menstruasi pada usia yang sama. Ketidakseimbangan antara asupan kebutuhan atau kecukupan akan menimbulkan masalah gizi lebih maupun gizi kurang. Status gizi yang normal akan mempengaruhi tercapainya usia menarche yang juga normal, dengan demikian terdapat hubungan yang bermaknaantara status gizi dengan usia menarche.

Menurut Purwitasari (2009) gizi adalah makanan dalam zat gizi dalam makanan yang berguna bagi kesehatan. Menurut Proverawati (2010), status gizi adalah ekspresi dari keadaan keseimbangan dalam bentuk variable tertentu atau perwujudan dari nurtriture dalam bentuk variable tertentu. Contoh gondok endemic merupakan keadaan tidak seimbangnya pemasukan dan pengeluaran yodium dalam tubuh.

Menurut asumsi peneliti terdapat hubungan status gizi dengan usia menstruasi pertama (menarche) pada siswi, status gizi sangat mempengaruhi denganusia menarche remaja putri yang mendapat menarche lebih dini, mereka cenderung lebih berat dan lebih tinggi pada saat menarche dibandingkan dengan yang belum menstruasi pada usia yang sama.

2. Hubungan Genetik dengan Usia Menstruasi Pertama (Menarche) pada Siswi

Berdasarkan hasilpenelitian yang telah dilakukan dapat menujukkan bahwa Setelah dilakukan uji korelasi person dan sperrman maka diperoleh nilai $P$ value $=0,000$, yang signifikanadanya hubungan genetik Dengan Usia Menstruasi Pertama (Menarche) Pada Siswi Smp Negeri 17 Banda AcehTahun 2016.

Menurut penelitian Nurrahmawati (2016), sangat erat hubungan antara usia menarche ibu dengan putrinya dan lebih erat lagi antar usia menarche wanita bersaudara. Hasil penelitiann yang dekemukakan oleh kisswardhani dalam penelitian Nurrahmawati (2016), mengatakan mengenai hubungan antara status gizi, tingkat paparan media massa dan faktor keturunan dengan usia menarche pada siswi SMP Negeri 1 Subah Batang didapatkan hasil bahwa ada hubungan antara faktor genetik dengan usia menarche.

Menurut penelitian Nurrahmawati (2016), sangat erat hubungan antara usia menarche ibu dengan putrinya dan lebih erat lagi antar usia menarche wanita bersaudara. 
Hasil penelitiann yang dekemukakan oleh kisswardhani dalam penelitian Nurrahmawati (2016), mengatakan mengenai hubungan antara status gizi, tingkat paparan media massa dan faktor keturunan dengan usia menarche pada siswi SMP Negeri 1 Subah Batang didapatkan hasil bahwa ada hubungan antara faktor genetik dengan usia menarche.

Pada waktu terjadinya kematangan seksual, seorang gadis mengikuti menstruasi pertama ibunya (Soetjitioningsih, 2007). Umur menarche ibu dapat mempengaruhi kecepatan pertumbuhan badan anak sehingga mempengaruhi waktu menstruasinya (Karis, 2011). Usia menarche ibu berkaitan dengan usia menarche anak, tidak hanya karena pengaruh genetik tapi juga bekaitan dengan lingkungan keluarga (Putri, 2009).

Menurut asumsi peneliti terdapat hubungan genetk dengan usia menstruasi pertama (menarche) pada Siswi. Genetik sangat mempengaruhi dengan usia menarche disebabkan genetik dianggap berpengaruh pada usia kematangan seorang wanita dan umur menarche ibu dapat mempengaruhi kecepatan pertumbuhan badan sehingga mempengaruhi waktu menstruasinya remaja putrinya.

\section{KESIMPULAN}

Berdasarkanhasil penelitian yang telahdilakukanmakadapat disimpulkan bahwa :

1. Ada hubungan yang sangat signifikan antar Status Gizi Dengan Usia Menstruasi Pertama (Menarche) Pada Siswi Smp Negeri 17 Banda AcehTahun 2016

2. Ada hubungan yang signifikan antara Genetik Dengan Usia Menstruasi Pertama (Menarche) Pada Siswi Smp Negeri 17 Banda AcehTahun 2016

\section{SARAN}

Terlebih dan sangat peting bagi tenaga kesehatan agar dapat lebih memaksimalkan dalam melakukan penyuluhan tentang kesehatan reproduksi remaja dan dapat dijadikan sebahai bahan tambahan dalam memberikan informasi kepada seluruh remaja perempuan.

\section{DAFTAR PUSTAKA}

Alamsyah, D. 2013. Pemberdayaan Gizi Teori Dan Aplikasi. Yogayakarta: Nuha

Amaliah. 2012. Status Tinggi Badan Pendek Beresiko Terhadap Keterlambatan Usia Menarche Pada Perempuan Remaja Usia 10-15 Tahun Dalam Situs http://ejournal.litbang.depkes.go.id/index.php/pgm/article/view/3383 di akses pada Febriari 2016 
Ariani, P. 2014. Aplikasi Metode Penelitian Kebidanan dan Kesehatan Reproduksi. Yogyakarta: Nuha Medika.

Aryani. 2010. Kesehatan Remaja. Jakarta: Salemba Medika.

Dahlan, S. 2010. Statistik Untuk Kedokteran Dan Kesehatan. Jakarta: Salemba Medika.

Eva, E, S.2012. Kesehatan Reproduksi. Jakarta: Trans Info Media.

Fitria. 2011. Hubungan Status Gizi Dengan Usia Menarche Pada Remaja Putri Di SMP $\begin{array}{lllll}\text { Negeri } & 222 & \text { Bandar Lampung Dalam }\end{array}$ http://juke.kedokteran.unila.ac.id/index.php/majority/article/download/36/35 $\mathrm{di}$ akses pada Februari 2016.

Guyton, A.C.2007. Buku Ajar Fisiologis Kedokteran. Ed. II. Jakrata: Hipokrates.

Hasdianah, S, Y. 2014. Gizi Pemanfaatan Gizi, Diet, dan Obesitas. Yogyakrta: Nuha Mediika.

Kesmas. 2013. Pemantauan Status Gizi Dalam Situs http://www.indonesia.public.health.com/diakses pada 10 Oktober 2013

Kumalasari, I. APP. 2012. Kesehatan Reproduksi Untuk Mahasiswa. Kebidanan Dan Keperawatan. Jakarta: Salemba Medika.

Kusmiran, E. 2013. Kesehatan Reproduksi Remaja Dan Wanita. Jakrta: Salemba Medika.

Liswidiyawati, R. 2012. Merawat Dan Menjaga Kesehatan Seksual Wanita. Bandung: PT Grafindo Media Pratama.

Maulidiah, F. 2011. Gambaran Status Gizi dan Genetik pada Kejadian Menarche di Perumahan Taman Pinang RW 05 Sidoarjo. STIKES YARSIS. Karya Tulis Ilmiah 2011. Medika.

Muryani, A. 2010. Biologi Reproduksi. Jakrata: Trans Info Medika

Notoatmodjo, S 2010. Metodelogi Penelitian Kesehatan. Jakarta: Rineka Cipta.

Nurrahmawati, 2016. Hubungan Status Gizi Dengan Usia Menarche Pada Remaja Putri Di $\begin{array}{llllll}\text { SMP Negeri } & 6 & \text { Tidore } & \text { Kepulauan Dalam }\end{array}$ http://ejournal.unsrat.ac.id/index.php/jkp/article/viewFile/10799/10388 di akses pada Februari 2016.

Proverawati, A. 2010. Ilmu Gizi Untuk Keperawatan Dan Gizi Kesehatan. Yogyakarta: Nuha Medika.

Proverawati, A. 2009. Menarche Menstruasi Penuh Makna. Yogyakarta: Nuha Medika.

Purwitasari, D. 2009. BukuAjar Gizi Dalam Kesehatan Reptoduksi. Yogyakarta: Nuha Medika.

Putri, AK. 2009. Hubungan antara Status Gizi, Status Menarche Ibu, Media Massa, Aktivitas Olahraga dengan Status Menarche Siswi di SMP Islam Al-Azhar Rawamangun, Jakarta Timur tahun 2009 (skripsi). Depok : Universitas Indonesia. 
Riset Kesehatan Dasar, (2010). http://dinkes.ntbprov.go.id/sistem/datadinkes/uploads/2013/10/Laporan_riskesdas_2010.pdf

Sarwono, P. 2008. Ilmu Kandungan.Jakarta: PT. Bina Pustaka.

Soetijioningsih. 2010. Tumbuh Kembang Remaja Dan Permasalahannya. Jakarta: Sagung Seto.

Soetijitioningsih. 2007. Tumbuh Kembang Remaja Dan Permasalahannya. Jakarta: Sagung Seto.

Winkjosasto, H. 2009. Ilmu Kandungan Ed. III. Jakrata: Yayasan Bina Pustaka Sarwono Prirahardjo 